\title{
Cytotoxic Effect of Polyisoprenoids from Rhizophora mucronata and Ceriops tagal Leaves against WiDr Colon Cancer Cell Lines
}

(Kesan Sitotoksik Poliisoprenoid daripada Daun Rhizophora mucronata dan Ceriops tagal terhadap Titisan Sel Kanser Kolon WiDr)

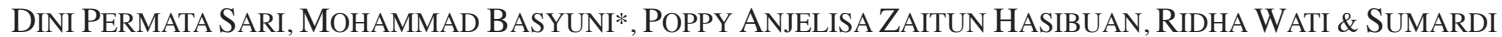

\begin{abstract}
The mangrove plant is known to produce secondary metabolite compounds, mainly isoprenoids. Polyisoprenoids (dolichol and polyprenol) are known to have antimicrobial, anticancer and antiviral activity. Therefore, this study aimed to determine the cytotoxic effects of polyisoprenoids from Rhizophora mucronata and Ceriops tagal leaves by evaluating the induction of apoptosis and cell cycle arrest and the inhibition of the expression of Bcl-2 and cyclin D1 in WiDr colon cancer cells. Cell death was determined based on $I C_{50}$ values in MTT assays. The induction of apoptosis and alterations in the cell cycle were observed by flow cytometry. The expression of Bcl-2 and cyclin D1 proteins, which play a role in apoptosis and cell cycle regulation, was observed by immunocytochemistry. The results showed that polyisoprenoids from $\mathrm{R}$. mucronata and $\mathrm{C}$. tagal leaves exhibited toxicity against the WiDr cell line, with $\mathrm{IC}_{50}$ values of $278 \pm 5.77$ and $276 \pm 9.54 \mu \mathrm{g} / \mathrm{mL}$, respectively. Polyisoprenoids from R. mucronata and C. tagal leaves significantly induced apoptosis and caused cell cycle arrest in G0/G1 phase, while also decreasing the expression of Bcl-2 and cyclin D1. Our results confirmed that polyisoprenoids from $\mathrm{R}$. mucronata and $\mathrm{C}$. tagal leaves have the potential to be developed as anticancer agents for colon cancer.
\end{abstract}

Keywords: Apoptosis; Ceriops tagal; cytotoxic; dolichol; Rhizophora mucronata

\section{ABSTRAK}

Tumbuhan bakau diketahui menghasilkan sebatian metabolit sekunder, terutamanya isoprenoid. Poliisoprenoid (dolichol dan poliprenol) diketahui mempunyai aktiviti antimikrob, antikanser dan antivirus. Oleh itu, kajian ini bertujuan untuk menentukan kesan sitotoksik poliisoprenoid daripada daun Rhizophora mucronata dan Ceriops tagal dengan menilai induksi apoptosis tangkapan kitaran sel serta kesan ekpresi Bcl-2 dan siklin D1 dalam titisan sel kanser kolon WiDr. Kematian sel ditentukan berdasarkan nilai $I_{50}$ dalam asai MTT. Induksi apoptosis dan perubahan dalam kitaran sel diperhatikan dengan aliran sitometri. Ekpresi Bcl-2 dan protein siklin D1 yang memainkan peranan dalam apoptosis dan kawal-selia kitaran sel diperhatikan melalui imunositokimia. Keputusan menunjukkan bahawa poliisoprenoid daripada daun R. mucronata dan C. tagal mengeluarkan ketoksikan terhadap titisan sel WiDr, masing-masing dengan nilai IC ${ }_{50}$ $278 \pm 5.77$ dan $276 \pm 9.54 \mu \mathrm{g} / \mathrm{mL}$. Poliisoprenoid daripada daun R. mucronata dan C. tagal dengan ketara mengaruh apoptosis dan menyebabkan tangkapan kitaran sel dalam fasa G0/G1, selain menurunkan ekspresi Bcl-2 dan siklin D1. Keputusan kami mengesahkan bahawa poliisoprenoid daripada daun R. mucronata dan C. tagal mempunyai potensi untuk dibangunkan sebagai agen anti-kanser untuk kanser kolon.

Kata kunci: Apoptosis; Ceriops tagal; dolichol; Rhizophora mucronata; sitotoksik

\section{INTRODUCTION}

Colorectal cancer, also referred to as colon cancer, is a malignant disease that occurs in the colon, rectum and appendix. Colon cancer is a deadly disease around the world that affects both men and women. Colon cancer is a leading cause of cancer deaths and ranking third for both sexes (Siegel et al. 2017). The incidence of colon cancer is about one million cases per year, with approximately 522,000 deaths per year (Ferlay et al. 2015). The pathophysiology of colon cancer involves several causes, such as changes in histopathologically normal colonic cells through molecular events. Another cause is the formation of adenomatous polyps that develop into colon cancer due to the process of carcinogenesis. Most colon cancers are adenocarcinomas (Corley et al. 2014). Chemotherapy is one of the treatments used for cancer, but it has unpleasant side effects, such as various skin reactions, hypersensitivity reactions, and peripheral neuropathy (Iwamoto 2013). Most of the currently used anticancer drugs, such as doxorubicin, have undesirable side effects, such as cardiotoxicity and tumour drug resistance (Leonard et al. 2009).

Alternative cancer treatments can be developed by utilizing naturally occurring compounds. Therefore, there is a need for research on alternative treatments for colon cancer to identify effective and efficient treatments based on natural ingredients. Various efforts to find alternative 
medicines are underway to identify drugs that have high efficacy but little-side effects for patients. One source that can be exploited for anticancer therapies is herbal medicine (Reddy et al. 2003). One group of plants that can be used for cancer treatment is the mangroves (Bandaranayake 1998). Mangroves are well known for producing secondary metabolite compounds, mainly isoprenoid. Polyisoprenoids are not toxic and are known to show some pharmacological activity as anticancer (Kuznecovs et al. 2007), antidyslipidemic (Singh et al.2007), anti-influenza and antiviral agents (Safatov et al. 2005). In previous studies, polyisoprenoids (>C30) have been isolated and characterized from mangrove forests in Iriomote Island, Japan, and North Sumatra, Indonesia (Basyuni et al. 2018, 2017, 2016).

Rhizophora mucronata and Ceriops tagal are two of the most widespread plants in Indonesia. $R$. mucronata has various benefits as an antiviral (Premanathan et al. 1996) and has antibacterial, cytotoxic, analgesic and diuretic activities (Howlader et al.2013). C. tagal also has various benefits such as antiviral (Sudheer et al.2011), antitumour (He et al. 2007), antimicrobial (Dhas et al. 2013) and antihyperglycaemic activity (Tiwari et al. 2008). These studies suggest that polyisoprenoids from $R$. mucronata and $C$. tagal leaves can act as chemopreventive agents, and they are also some of the most important mangrove species to be investigated.

This research aimed to examine the cytotoxic activity of polyisoprenoids from $R$. mucronata and $C$. tagal leaves against WiDr colon cancer cell lines. These compounds inhibited the cell cycle and induced apoptosis of WiDr cells through the inhibition of $\mathrm{Bcl}-2$ and cyclin $\mathrm{D} 1$ proteins. The results of this study are expected to be the basis for the development of polyisoprenoids from $R$. mucronata and $C$. tagal leaves as anticancer agents for colon cancer.

\section{MATERIALS AND METHODS}

\section{PLANT MATERIALS AND ISOLATION OF POLYISOPRENOIDS}

The leaves of $R$. mucronata and $C$. tagal were obtained from Lubuk Kertang, Langkat, North Sumatera province, Indonesia. The isolation of polyisoprenoids was performed as previously described (Arifiyanto et al. 2017; Basyuni et al. 2017, 2016). The leaves of $R$. mucronata and C.tagal were dried at room temperature for a week and ground into powder. The dried leaves powder $(500 \mathrm{~g})$ extracted with a mixture of chloroform methanol with a ratio 2:1 (2 chlorofrom: 1 methanol, v/v) solvent for $48 \mathrm{~h}$. The lipid extract from the leaves was saponified at $65^{\circ} \mathrm{C}$ for $24 \mathrm{~h}$ in $86 \%$ ethanol containing $2 \mathrm{M} \mathrm{KOH}$. The nonsaponifiable lipids were extracted with hexane, and the organic solvent was evaporated and re-dissolved in hexane.

\section{CELL LINE AND CULTURE CONDITIONS}

WiDr cells (colon adenocarcinoma) were kindly provided by the Parasitology Laboratory, Faculty of Medicine,
Gadjah Mada University, Yogyakarta, Indonesia. The cells were cultured in RPMI 1640 medium (Gibco, Carlsbad, CA, USA) supplemented with $10 \%(\mathrm{v} / \mathrm{v})$ foetal bovine serum (FBS) (Sigma-Aldrich, St. Louis, MO, USA), 2\% penicillinstreptomycin (Sigma-Aldrich, St. Louis, MO, USA), and $0.5 \%$ fungizone (Sigma-Aldrich, St. Louis, MO, USA), in a $37^{\circ} \mathrm{C}$ incubator with $5 \% \mathrm{CO}_{2}$ (Heraeus).

\section{PREPARATION OF STOCK SOLUTION}

Respectively $50 \mathrm{mg}$ polyisoprenoids from $R$. mucronata and $50 \mathrm{mg}$ polyisoprenoids from $C$. tagal was dissolved in $10 \mathrm{~mL}$ of RPMI 1640 medium with the help of $1 \mathrm{~mL}$ of DMSO (Sigma-Aldrich, St. Louis, MO, USA) to obtain a concentration of $5000 \mu \mathrm{g} / \mathrm{mL}$. With a multilevel dilution scheme, a range of concentrations was obtained (15.625, $31.25,62.50,125,250$ and $500 \mu \mathrm{g} / \mathrm{mL}$ ).

\section{CYTOTOXICITY TEST}

WiDr cells were grown in 96-well microplates to obtain a density of $5 \times 10^{3}$ cells/well and incubated at $5 \% \mathrm{CO}_{2}$ and $37^{\circ} \mathrm{C}$ for $24 \mathrm{~h}$ to achieve confluent growth. Afterwards, the diluted test samples with the co-solvent DMSO were added to the medium and the cells were incubated at $37^{\circ} \mathrm{C}$ in $5 \% \mathrm{CO}_{2}$ for $24 \mathrm{~h}$. At the end of the incubation, the medium containing the extracts was discarded and the cells were washed with PBS. Next, $100 \mu \mathrm{L}$ of RPMI culture medium and $10 \mu \mathrm{L}$ of MTT (Sigma-Aldrich, St. Louis, MO, USA) at a concentration of $5 \mathrm{mg} / \mathrm{mL}$ were added to each well. The cells were incubated for 4-6 h in $5 \% \mathrm{CO}_{2}$ at $37^{\circ} \mathrm{C}$. The MTT reaction was stopped with $10 \%$ sodium dodecyl sulphate (Sigma-Aldrich, St. Louis, MO, USA) in $0.01 \mathrm{~N} \mathrm{HCl}$ (Merck, Darmstadt, Germany) and the plate was then wrapped and left for overnight at room temperature. The absorption was read on an ELISA reader (Benchmark Bio-Rad, Hercules, CA, USA) at 595 $\mathrm{nm}$ wavelength. The data obtained in the form of the absorbance of each well were converted into the percent cell viability. Then, to recover linearity between the $\log$ concentration and cell viability, the $\mathrm{IC}_{50}$ value was calculated using probit analysis in SPSS.

\section{MEASUREMENT OF APOPTOTIC CELLS AND CELL CYCLE DISTRIBUTION USING FLOW CYTOMETRY}

WiDr cells were grown on 6-well plates with each well containing $1 \times 10^{6}$ cells in a $5 \% \mathrm{CO}_{2}$ incubator at $37^{\circ} \mathrm{C}$ for $24 \mathrm{~h}$. After incubation for $24 \mathrm{~h}$, extracts at concentrations of $1 \mathrm{IC}_{50}, 1 / 2 \mathrm{IC}_{50}, 1 / 5 \mathrm{IC}_{50}$ and $1 / 10 \mathrm{IC}_{50}$ were added to each well and the plates were incubated under the same conditions as previously described. Then, the medium was removed from each well and placed in $15 \mathrm{~mL}$ conical tubes and the cells were washed with PBS. Trypsin $(250 \mu \mathrm{L})$ was added to each well and the cells were incubated for $3 \mathrm{~min}$ in the $\mathrm{CO}_{2}$ incubator; then, the liquid was placed in an Eppendorf tube and centrifuged at $2500 \mathrm{rpm}$ for $5 \mathrm{~min}$. The cells in each Eppendorf tube were washed with cold PBS by centrifugation at $1500 \mathrm{rpm}$. For apoptotic testing, 
annexin V (BioLegend, San Diego, CA, USA) and propidium iodide (BioLegend, San Diego, CA, USA) were added, while for cell cycle testing, added only propidium iodide and incubated the cells for $10 \mathrm{~min}$ in the dark. The flow cytometry analysis was performed by using FACSVerse (BD Biosciences) after less than $1 \mathrm{~h}$. The results were analysed using CellQuest Pro software.

\section{IMMUNOCYTOCHEMISTRY ASSAY}

WiDr cells were grown in a 24 well-plate with a coverslip whereby in each well $5 \times 10^{4}$ cells/well were added and then grown in a $5 \% \mathrm{CO}_{2}$ incubator at $37^{\circ} \mathrm{C}$ for $24 \mathrm{~h}$. Then, added an extract at a concentration of $1 \mathrm{IC}_{50}$ and incubated the cells further. After $24 \mathrm{~h}$, the cells were washed with PBS and cold methanol was added. Then, added $3 \% \mathrm{H}_{2} \mathrm{O}_{2}$ in PBS, pH7.4, to each of the wells, followed by blocking buffer and incubated the cells for $1 \mathrm{~h}$. Then, each well was incubated for at least $1 \mathrm{~h}$ with the relevant primary antibody (human anti-Bcl-2/anti-cyclin D1) (Santa Cruz Biotechnology, Dallas, TX, USA) at a 1:100 dilution in PBS with $1 \%$ FBS. Secondary antibody a biotinylated anti-rabbit IgG (Vector Laboratories, Inc., Burlingame, CA, USA) was then added to each well and the plates were incubated at room temperature for $10 \mathrm{~min}$ and then washed with PBS. A 3,3'-diaminobenzidine solution, as the chromogen, was added to the cells for $5 \mathrm{~min}$. Next, washed the plates with distilled water, stained the cells with haematoxylin and visualized the colour reaction. Bcl-2 and cyclin D1 protein expression was observed using an inverted light microscope (Olympus, Tokyo, Japan) and documented.

\section{DATA ANALYSIS}

Data were presented as the mean \pm SD of at least three independent experiments. Data were analysed by one-way analysis of variance (ANOVA) followed by Duncan's test for comparisons of all treatments. All statistical analyses were performed using SPSS version 23. Differences were considered significant at $p<0.05$.

\section{RESULTS}

\section{EFFECT OF POLYISOPRENOIDS FROM R. MUCRONATA AND} C. TAGAL LEAVES ON CELL VIABILITY

A cytotoxic test was performed to determine the toxicity potential of polyisoprenoids from $R$. mucronata and $C$. tagal leaves expressed as the $\mathrm{IC}_{50}$. Treatment of WiDr cells with polyisoprenoids from $R$. mucronata and $C$.tagal leaves extract over a concentration range of 15.625,31.25, $62.525,125,250$ and $500 \mu \mathrm{g} / \mathrm{mL}$ showed the $\mathrm{IC}_{50}$ values of polyisoprenoids from $R$. mucronata and $C$. tagal leaves to be $278 \pm 5.77 \mu \mathrm{g} / \mathrm{mL}$ and $276 \pm 9.54 \mu \mathrm{g} / \mathrm{mL}$, respectively. Polyisoprenoids from $R$. mucronata and $C$. tagal leaves showed a dose-dependent inhibitory effect on WiDr cells after $24 \mathrm{~h}$ of treatment (Figure 1).
EFFECTS OF POLYISOPRENOIDS FROM MANGROVE LEAVES ON APOPTOSIS AND CELL CYCLE ARREST OF WIDR CELLS

Staining with annexin $\mathrm{V}$ and propidium iodide to detect apoptosis using an Annexin V-FITC Apoptotic Kit showed increased apoptosis in WiDr cells exposed to polyisoprenoids from $R$. mucronata and $C$.tagal leaves for $24 \mathrm{~h}$ compared with control cells (Figure 2). The percentage of dead cells and the rate of apoptosis increased in a dosedependent fashion.

To investigate the cytotoxic mechanisms of polyisoprenoids from $R$. mucronata and $C$. tagal leaves, the cell cycle distribution of WiDr cells treated with various concentrations of polyisoprenoids from $R$. mucronata and $C$. tagal leaves was examined by a FACScan flow cytometer. Our results showed that the number of WiDr cells arrested in $\mathrm{G} 0 / \mathrm{G} 1$ increased after exposure to polyisoprenoids from $R$. mucronata and C. tagal leaves compared with that of control cells (Table 1).

\section{INHIBITION OF BCL-2 AND CYCLIN D1 PROTEIN EXPRESSION}

As shown in Figure 3, immunocytochemistry analysis of Bcl-2 and cyclin D1 protein expression in WiDr cells $\left(5 \times 10^{4}\right.$ cells $\left./ \mathrm{mL}\right)$ treated with polyisoprenoids from $R$. mucronata and $C$.tagal leaves resulted in down-regulation of Bcl-2 and cyclin D1 compared with control cells.

Based on the immunocytochemical test results, we confirmed the semi-quantitative analysis. Polyisoprenoids from $R$. mucronata and $C$. tagal leaves significantly suppressed Bcl-2 and cyclin D1 expression in WiDr cells $(p<0.05)$ (Table 2). These data suggested that polyisoprenoids from $R$. mucronata and $C$. tagal leaves inhibited the expression of Bcl-2 and cyclin D1 in WiDr cells.

\section{DISCUSSION}

The cytotoxicity test in this study was conducted to determine the potential toxicity of polyisoprenoids from $R$. mucronata and $C$.tagal leaves against the colon cancer WiDr cell line. The cytotoxic activity of polyisoprenoids from $R$. mucronata and $C$. tagal leaves was determined by MTT method by looking at cell viability which one of anticancer activity test based on cell ability to survive exposure to toxic compounds (Ulukaya et al. 2008). The cytotoxic nature is a major step in the discovery of new anticancer drugs derived from nature (Harvey et al. 2015). In this study as shown in Figure 1, administration of polyisoprenoids from $R$. mucronata and $C$.tagal leaves can cause death of colon cancer cell WiDr at highest dose is $278 \pm 5.77 \mu \mathrm{g} / \mathrm{mL}$ and $276 \mu \mathrm{g} / \mathrm{mL} \pm 9.54$, respectively. This suggests that the higher concentration of the test samples given the smaller percentage of cancer cell life and the greater the toxicity.

Polyisoprenoids contained in the leaves of $R$. mucronata and $C$. Tagal were shown cell cycle arrest and induced apoptosis as shown through flow cytometry. 


\section{R. mucronata}

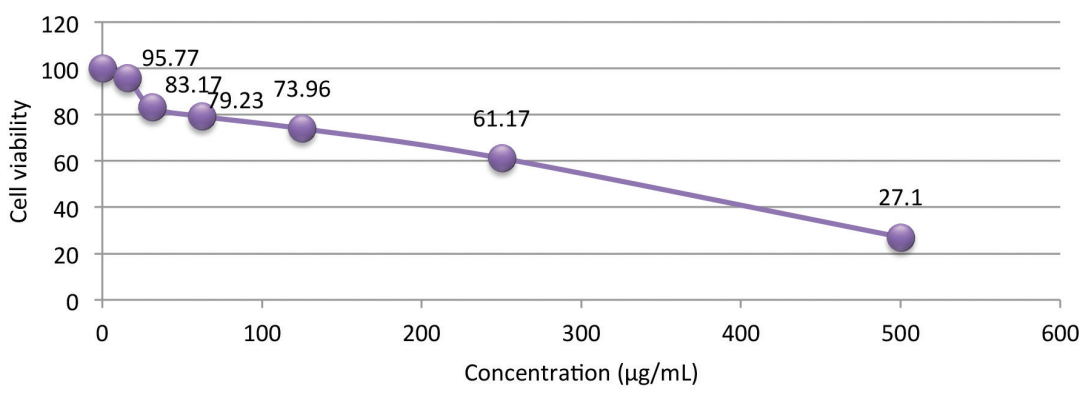

(a)

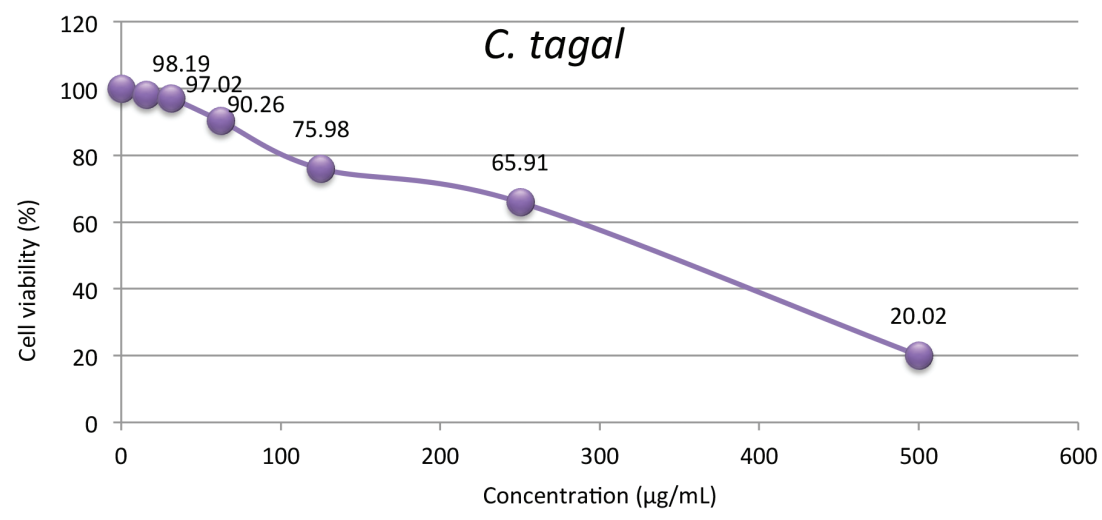

(b)

FIGURE 1. Percentage of growth inhibition of WiDr cells after treatment with polyisoprenoids from $R$. mucronata and C. tagal leaves (a) Polyisoprenoids from R. mucronata leaves (b) Polyisoprenoids from C.tagal leaves

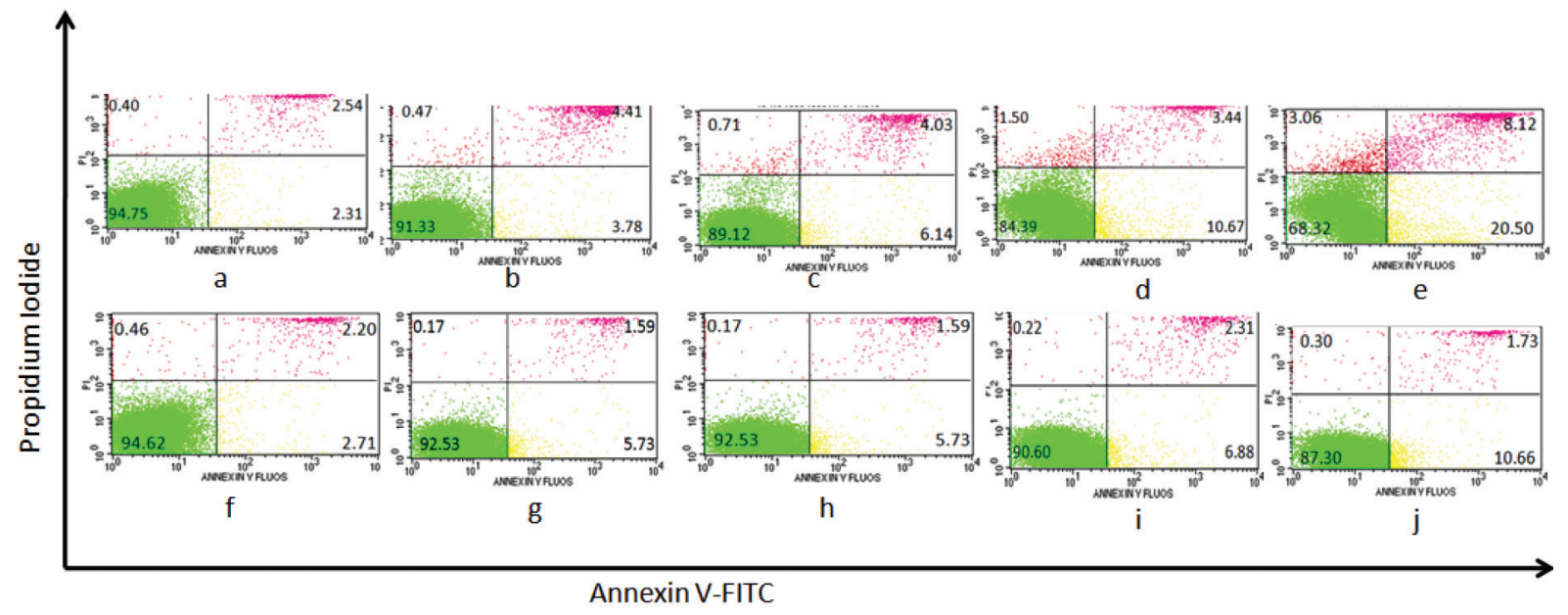

PRM= Polyisoprenoids from R. mucronata PCT= Polyisoprenoids from C. tagal. Each value represents the mean of three independent experiments

FIGURE 2. Apoptosis assay using flow cytometry after annexin V-FITC and propidium iodide (PI) staining (a) Untreated cells, (b) PRM at $27.8 \mu \mathrm{g} / \mathrm{mL}$, (c) PRM at $55.6 \mu \mathrm{g} / \mathrm{mL}$, (d) PRM at $139 \mu \mathrm{g} / \mathrm{mL}$, (e) PRM at $278 \mu \mathrm{g} / \mathrm{mL}$, (f) Untreated cells, (g) PCT $27.6 \mu \mathrm{g} / \mathrm{mL}$, (h) PCT $55.2 \mu \mathrm{g} / \mathrm{mL}$, (1) PCT $138 \mu \mathrm{g} / \mathrm{mL}$, (j) PCT $276 \mu \mathrm{g} / \mathrm{mL}$

The inhibition of cell cycle is an important strategy for controlling the growth of cancer cells (Qui et al. 2011). From the results of this study, cell accumulation at the G0/G1 phase was observed in WiDr cells treated with polyisoprenoids from $R$. mucronata and $C$. tagal leaves (Table 1). The inhibition of cell cycle at phase G0/G1 may be contributed by the presence of polyisoprenoids in leaves of R. mucronata and C.tagal (Elson et al. 1999). Mo 
TABLE 1. Cell cycle distribution of WiDr cells after treatment with polyisoprenoids from $R$. mucronata and $C$. tagal leaves

\begin{tabular}{|c|c|c|c|c|}
\hline \multirow{2}{*}{ Treatment } & \multirow{2}{*}{$\begin{array}{c}\text { Concentration } \\
\mu \mathrm{g} / \mathrm{mL}\end{array}$} & \multicolumn{3}{|c|}{$\%$ Cells in each phase } \\
\hline & & $\mathrm{G} 0 / \mathrm{G} 1$ & $\mathrm{~S}$ & $\mathrm{G} 2 / \mathrm{M}$ \\
\hline Control & 0 & 64.53 & 18.20 & 17.00 \\
\hline \multirow{4}{*}{ Polyisoprenoids from $R$. mucronata leaves } & $27.8\left(1 / 10 \mathrm{IC}_{50}\right)$ & $64.93 \pm 0.53$ & $13.73 \pm 0.36$ & $19.19 \pm 0.64$ \\
\hline & $55.6\left(1 / 5 \mathrm{IC}_{50}^{50}\right)$ & $67.42 \pm 0.66$ & $13.32 \pm 0.52$ & $20.77 \pm 0.61$ \\
\hline & $139\left(1 / 2 \mathrm{IC}_{50}\right)$ & $66.23 \pm 0.42$ & $27.35 \pm 0.39$ & $8.27 \pm 0.41$ \\
\hline & $278\left(1 \mathrm{IC}_{50}\right)$ & $66.38 \pm 0.71$ & $18.87 \pm 0.42$ & $14.93 \pm 0.53$ \\
\hline \multirow{4}{*}{ Polyisoprenoids from $C$. tagal leaves } & $27.6\left(1 / 10 \mathrm{IC}_{50}\right)$ & $69.11 \pm 0.59$ & $14.73 \pm 0.38$ & $19.19 \pm 0.61$ \\
\hline & $55.2\left(1 / 5 \mathrm{IC}_{50}\right)$ & $73.64 \pm 0.35$ & $12.15 \pm 0.54$ & $20.77 \pm 0.46$ \\
\hline & $138\left(1 / 2 \mathrm{IC}_{50}\right)$ & $70.60 \pm 0.51$ & $16.10 \pm 0.44$ & $8.27 \pm 0.69$ \\
\hline & $276\left(1 \mathrm{IC}_{50}\right)$ & $68.51 \pm 0.38$ & $17.40 \pm 0.61$ & $14.93 \pm 0.57$ \\
\hline
\end{tabular}

Data are presented as the mean $\pm \mathrm{SD}, n=3$

(a)

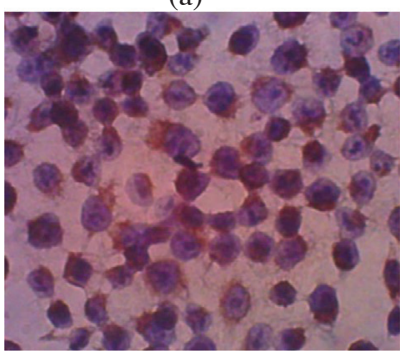

(c)

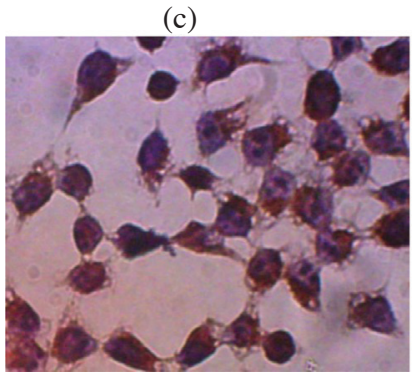

(b)

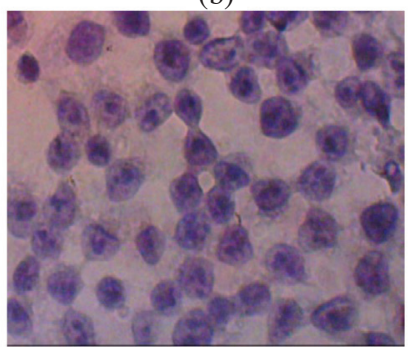

(d)

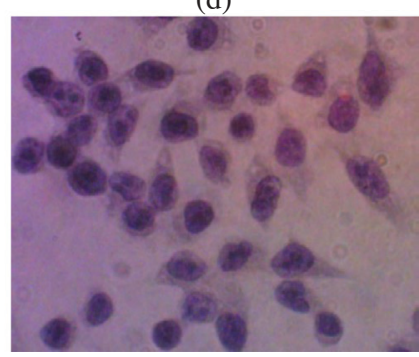

Brown colour: Bcl-2 and cyclin D1 expression

FIGURE 3. The observation of Bcl-2 and cyclin D1 expression in cells by immunocytochemistry under a light microscope at 400× magnification (a) Untreated cells (Bcl-2 negative control), (b) cells treated with $278 \mu \mathrm{g} / \mathrm{mL}$ polyisoprenoids from $R$. mucronata leaves, (c) untreated cells (cyclin D1 negative control), and (d) cells treated with $276 \mu \mathrm{g} / \mathrm{mL}$ polyisoprenoids from $C$. tagal leaves

and elson (2004) demonstrated isoprenoid synergistically inhibits human DU145 and LNCaP prostate carcinoma and murine B16 melanoma cells. This isoprenoid induces G1 arrest and initiates apoptosis and differentiation, an effect associated with modulating the cellular signal pathway by either modulating gene expression, suppressing translational signal processing and post-translational growth factor receptors, or altering dlacylglycerol signals (Mo \& Elson 2004). Isoprenoid also induces G1 growth capture in GBM cells (A172, U87 and U251) and breast cancer cells (MDA-MB-231, 432, 435) (Jiang et al. 2014). Polyisoprenoids from $R$. mucronata and $C$. tagal proven caused cancer cells die. Polyisoprenoids from $R$. mucronata and $C$. tagal leaves has been reported to contain $100 \%$ dolichol (C75-C90) but no polyprenol detected (Basyuni et al. 2017). Treatment with dolichol significantly interferes with the function of Ras and Rho GTPase family, with inhibition of cyclin-dependent kinases (CDKs) and activation of CDK inhibitors (Jakobisiak \& Golab 2003). Dolichol is one of the derivatives of mevalonic acid. Mevalonic acid is a precursor in the biosynthesis of isoprenoid compounds, enabling proper functional and cellular refinement of many proteins such as Ras and Rho (Wiemer et al. 2009). In several previous studies dolichol significantly delayed growth arrest in human breast cancer cells Hs578T and MDA231 (Larsson 1994).

In this study, treatment of cancer cells (the colon cancer cell line WiDr) with polyisoprenoids from $R$. mucronata and C.tagal leaves suppressed the expression of Bcl-2 and cyclin D1 protein (Table 2; Figure 2) and induced apoptosis (Figure 1). Previous studies of isoprenoid have been shown to induce apoptosis (Holstein \& Hohl 2004; 
TABLE 2. Number of cells that expressed Bcl-2 and cyclin D1

\begin{tabular}{lcc}
\hline \multicolumn{1}{c}{ Treatment } & \% Expression of Bcl-2 & \% Expression of cyclin D1 \\
\hline Untreated & $63.18 \pm 10.63$ & $72.16 \pm 8.51$ \\
\hline Polyisoprenoids from R. mucronata leaves & $32.96 \pm 5.48^{*}$ & $20.83 \pm 4.83^{*}$ \\
Polyisoprenoids from C. tagal leaves & $37.16 \pm 4.29^{*}$ & $32.93 \pm 5.17^{*}$ \\
\hline
\end{tabular}

Data are presented as the mean $\pm \mathrm{SD}, n=3{ }^{*}$ significant difference compared with untreated cells $(p<0.05)$

Sakagami et al. 2000). One such group of phytochemicals the terpenoids is found in nature. Terpenoids, also referred to as terpenes or isoprenoid, are phytochemicals present in $R$. mucronata and C. tagal leaves including lupanes, dammaranes, oleans and dolabranes (Nebula et al. 2013; Zhang et al. 2005). Some of these compounds are known to provide an overview of the antitumor potential of these agents against various cancers (Bishayee et al. 2011; Laszczyk \& Pentacyclic 2009; Liby et al. 2007; Petronelli 2009; Setzer \& Setzer 2003). One of the derivates lupanes is found in the leaves of $R$. mucronata and $C$. tagal that causing simultaneous apoptotic induction, decreased Bcl-2 and cyclin D1 and increased Bax gene expression (Bishayee et al. 2011). The transition of cell cycle from one phase to another depends on the complex regulation of cyclin-dependent kinases (CDKs), the active agent that phosphorylates substrate involved in the cell cycle. The G1 phase to $\mathrm{S}$ phase of the cell cycle is controlled by a number of cyclin members, including cyclin D1 (Otto \& Sicinski 2017). Previous research has shown that excessive expression of cyclone D is seen in many human cancers (Vermuelen et al. 2003). Inhibition of cyclin D1 expression is considered an excellent target in searching for possible chemotherapy and chemo preventative agents.

\section{CONCLUSION}

In summary, the results obtained from this study showed that polyisoprenoids from $R$. mucronata and $C$. tagal leaves have cytotoxic effects via apoptosis and arresting the human colon cancer cell line WiDr at the G0/G1 phase. Polyisoprenoids from $R$. mucronata and $C$. tagal leaves appear to be apoptosis-inducing agents and to cause arrest in $\mathrm{G} 0 / \mathrm{G} 1$ phase by down-regulating the protein expression of Bcl-2 and cyclin D1, which both play an essential role in apoptosis and cell cycle arrest. These present data can facilitate the development of new treatments for colon cancer and other malignancies that are difficult to treat and are life-threatening.

\section{REFERENCES}

Arifiyanto, D., Basyuni, M., Sumardi, Putri, L.A.P., Siregar, E.S., Risnasari, I. \& Syahputra, I. 2017. Occurrence and cluster analysis of palm oil (Elaeis guineensis) fruit type using two-dimensional thin layer chromatography. Biodiversitas 18: 1487-1492.

Bandaranayake, W.M. 1998. Traditional and medicinal uses of mangroves. Mangroves and Salt Marshes 2: 133-148.
Basyuni, M., Wati, R., Sagami, H., Sumardi, Baba, S. \& Oku, H. 2018. Diversity and abundance of polyisoprenoid composition in coastal plant species from North Sumatra, Indonesia. Biodiversitas 19: 1-11.

Basyuni, M., Sagami, H., Baba, S. \& Oku, H. 2017. Distribution and occurrence of new polyprenyl acetone and other polyisoprenoids in Indonesian mangroves. Dendrobiology 78: $18-31$.

Basyuni, M., Sagami, H., Baba, S., Iwasaki, H. \& Oku, H. 2016. Diversity of polyisoprenoids in ten Okinawan Mangroves. Dendrobiology 75: 167-175.

Bishayee, A., Ahmed, S., Brankov, N. \& Perloff, M. 2011. Triterpenoids as potential agents for the chemoprevention and therapy of breast cancer. Frontiers in Bioscience: A Journal and Virtual Library 16: 980-986.

Corley, D.A., Jensen, C.D., Marks, A.R., Zhao, W.K., Lee, J.K., Doubeni, C.A., Zauber, A.G., Boer, J.D., Fireman, B.H., Schottinger, J.E., Quinn, V.P., Ghai, N.R., Levin, T.R. \& Quesenberry, C.P. 2014. Adenoma detection rate and risk of colorectal cancer and death. New England Journal of Medicine 370: 1298-1306.

Dhas, S.P., Mukherjee, A.M.I.T.A.V.A. \& Chandrasekaran, N. 2013. Photosynthesis of silver nanoparticles using Ceriops tagal and its antimicrobial potential against human pathogens. International Journal of Pharmacy and Pharmaceutical Sciences 5: 349-352.

Elson, C.E., Peffley, D.M., Hentosh, P. \& Mo, H. 1999. Isoprenoid-mediated inhibition of mevalonate synthesis: Potential application to cancer. Proceedings of the Society for Experimental Biology and Medicine 221: 294-311.

Ferlay, J., Soerjomataram, I., Dikshit, R., Eser, S., Mathers, C., Rebelo, M., Parkin, D.W., Forman, D. \& Bray, F. 2015. Cancer incidence and mortality worldwide: Sources, methods and major patterns in GLOBOCAN 2012. International Journal of Cancer 136: 359-386.

Harvey, A.L., Edrada-Ebel, R. \& Quinn, R.J. 2015. The reemergence of natural products for drug discovery in the genomics era. Nature Reviews Drug Discovery 14: 111-129.

He, L., Wang, Y.S. \& Wang, Q.J. 2007. In vitro antitumor activity of triterpenes from Ceriops tagal. Natural Product Research 21: $1228-1233$.

Holstein, S.A. \& Hohl, R.J. 2004. Isoprenoids: Remarkable diversity of form and function. Lipids 39: 293-309.

Howlader, M., Islam, S., Ahmed, M., Kabir, A.N.M., Uddin, M. \& Hossain, M. 2013. Antibacterial, cytotoxic, analgesic and diuretic activities of Rhizophora mucronata Lam. bark. Indian Journal of Natural Products and Resources 4: 229-232.

Iwamoto, T. 2013. Clinical application of drug delivery systems in cancer chemotherapy: Review of the efficacy and side effects of approved drugs. Biological and Pharmaceutical Bulletin 36: 715-718.

Jakobisiak, M. \& Golab, J. 2003. Potential antitumor effects of statins. International Journal of Oncology 23: 1055-1069. 
Jiang, P., Mukthavaram, R., Chao, Y., Nomura, N., Bharati, I.S., Fogal, V., Pastorino, S., Teng, D., Cong, X., Pingle, S.C., Kapoor, S., Shetty, K., Aggrawal, A., Vali, S., Abbasi, T., Chien, S. \& Kesari, S. 2014. In vitro and in vivo anticancer effects of mevalonate pathway modulation on human cancer cells. British Journal of Cancer 111: 1562-1571.

Kuznecovs, S., Jegina, K. \& Kuznecovs, I. 2007. Inhibition of P-glycoprotein by polyprenol in human breast cancer cells. The Breast 16: 515-521.

Larsson, O. 1994. Effects of isoprenoids on growth of normal human mammary epithelial cells and breast cancer cells in vitro. Anticancer Research 14: 123-128.

Laszczyk, M.N. 2009. Pentacyclic. Triterpenes of the lupane, oleanane and ursane group as tools in cancer therapy. Planta Medica 75: 1549-1560.

Leonard, R.C.F., Williams, S., Tulpule, A., Levine, A.M. \& Oliveros, S. 2009. Improving the therapeutic index of anthracycline chemotherapy: Focus on liposomal doxorubicin (Myocet $^{\mathrm{TM}}$ ). The Breast 18: 218-224.

Liby, K.T., Yore, M.M. \& Sporn, M.B. 2007. Triterpenoids and rexinoids as multifunctional agents for the prevention and treatment of cancer. Nature Reviews Cancer 7: 357-369.

Petronelli, A., Pannitteri, G. \& Testa, U. 2009. Triterpenoids as new promising anticancer drugs. Anti-Cancer Drugs 20: 880-892.

Mo, H. \& Elson, C.E. 2004. Studies of the isoprenoid-mediated inhibition of mevalonate synthesis applied to cancer chemotherapy and chemoprevention. Experimental Biology and Medicine 229: 567-585.

Nebula, M., Harisankar, H.S. \& Chandramohanakumar, N. 2013. Metabolites and bioactivities of Rhizophoraceae mangroves. Natural Products and Bioprospecting 3: 207-232.

Otto, T. \& Sicinski, P. 2017. Cell cycle proteins as promising targets in cancer therapy. Nature Reviews Cancer 17: 93-115.

Premanathan, M., Nakashima, H., Kathiresan, K., Rajendran, N. \& Yamamoto, N. 1996. In vitro anti human immunodeficiency virus activity of mangrove plants. Indian Journal of Medical Research 103: 278-281.

Qui, P., Guan, H., Dong, P., Li, S., Ho, C.T., Pan, M.S., McClements, D.J. \& Xiao, H. 2011. The p53-, Bax- and p21-dependent inhibition of colon cancer cell growth by 5-hydroxy polymethoxyflavones. Molecular Nutrition Food Research 55: 613-22.

Reddy, L., Odhav, B. \& Bhoola, K.D. 2003. Natural products for cancer prevention: A global perspective. Pharmacology \& Therapeutics 99: 1-13.

Safatov, A.S., Boldyrev, A.N., Bulychev, L.E., Buryak, G.A, Kukina, T.P., Poryvaev, V.D., P'Yankov, O.V., Raldugin, V.A., Ryzhikov, A.B., Sergeev, A.N., Shishkina, L.N., Tolstikov, G.A. \& Zhukov, V.A. 2005. A prototype prophylactic anti-influenza preparation in aerosol form on the basis of Abiessibirica polyprenols. Journal of Aerosol Medicine 18: 55-62.

Sakagami, H., Jiang, Y., Kusama, K., Atsumi, T., Ueha, T., Toguchi, M., Iwakura, I., Satoh, K., Fukai, T. \& Nomura, T. 2000. Induction of apoptosis by flavones, flavonols (3-hydroxyflavones) and isoprenoid-substituted flavonoids in human oral tumor cell lines. Anticancer Research 20: 271-277.
Setzer, W.N. \& Setzer, M.C. 2003. Plant-derived triterpenoids as potential antineoplastic agents. Mini-Reviews in Medicinal Chemistry 3: 540-556.

Siegel, R.L., Miller, K.D., Fedewa, S.A., Ahnen, D.J., Meester, R.G., Barzi, A. \& Jemal, A. 2017. Colorectal cancer statistics. 2017. CA: Cancer Journal for Clinicians 67: 177-193.

Singh, G., Gupta, P., Rawat, P., Puri, A., Bhatia, G. \& Maurya, R. 2007. Antidyslipidemic activity of polyprenol from Cocciniagrandis in high-fat diet fed hamster model. Phytomedicine 14: 792-798.

Sudheer, N.S., Philip, R. \& Singh, I.B. 2011. In vivo screening of mangrove plants for anti WSSV activity in Penaeus monodon, and evaluation of Ceriops tagal as a potential source of antiviral molecules. Aquaculture 311: 36-41.

Tiwari, P., Tamrakar, A.K., Ahmad, R., Srivastava, M.N., Kumar, R.,Lakshmi, V. \& Srivastava, A.K. 2008. Antihyperglycaemic activity of Ceriops tagal in normoglycaemic and streptozotocin-induced diabetic rats. Medicinal Chemistry Research 17: 74-84.

Ulukaya, E., Ozdikicioglu,F., Oral,A.Y. \& Demirci, M. 2008. The MTT assay yields a relatively lower result of growth inhibition than the ATP assay depending on the chemotherapeutic drugs tested. Toxicology in Vitro 22: 232-239.

Vermuelen, K., Van Bockstaele, D.R. \& Berneman, Z.N. 2003. The cell cycle: A review of regulation, deregulation and therapeutic targets in cancer. Cell Proliferation 36: 131-149.

Wiemer,A.J., Hohl, R.J. \& Wiemer, D.F. 2009. The intermediate enzymes of isoprenoid metabolism as anticancer targets. Anticancer Agents in Medisinal Chemistry 9: 525-542.

Zhang, C.X., Yan, S.J., Zhang, G.W., Lu, W.G., Su, J.Y. \& Zeng, L.M. 2005. Cytototxic diterpenoid from soft coral Sinularia microclavata. Journal of Natural Products 68: 1087-1089.

Dini Permata Sari \& Poppy Anjelisa Zaitun Hasibuan Faculty of Pharmacy

Universitas Sumatera Utara Jl. Tri Dharma No. 5

Pintu 4 USU Campus, Medan 20155

Indonesia

Mohammad Basyuni* \& Ridha Wati

Department of Forestry

Faculty of Forestry

Universitas Sumatera Utara, Jl. Tri Dharma Ujung No. 1

Medan, North Sumatra, 20155

Indonesia

Sumardi

Faculty of Pharmacy

Universitas Tjut Nyak Dhien, Jl. Rasmi No. 28

Medan, 20123

Indonesia

*Corresponding author; email: m.basyuni@usu.ac.id

Received: 15 December 2017

Accepted: 16 May 2018 